\title{
GEOMORPHIC PROCESSES ABOVE TIMBERLINE IN THE SPANISH PYRENEES
}

\author{
Jose M. Gargia-Ruizi , Bernardo Alvera1, Gabriel Del Barrio ${ }^{1}$, and Juan Puigdefabregas²
}

\begin{abstract}
This paper presents a general account of geomorphic processes effective above timberline in the Spanish Pyrenees with emphasis on the central section of the range. Climatic and environmental factors are discussed in detail as well as the geomorphic responses to lowering of the upper timberline, especially between the sixteenth and ninetcenth centuries. During this period expansion of livestock grazing reduced the forest cover extensively and caused a substantial lowering of the lower altitudinal limit of periglacial activity. Relic periglacial forms are attributable to the Late Quaternary Period, although many active forms are present today. These include rock glaciers, solifluction lobes and terracettes, and various types of patterned ground. Altitude, exposure, slope gradient, and lithology are shown to be important determinant factors, together with the increasing degree of continentality in the Central Pyrenees compared with areas further west and east respectively. The high mountain region is divided into two altitudinal belts with the $2,400 \mathrm{~m}$ level forming the general boundary.
\end{abstract}

RÉsumé Processus géomorphiques au-dessus de la limite des arbres dans les Pyrénées espagnoles. Cet article donne un aperçu général des processus géomorphiques qui se produisent au-dessus de la limite des arbres dans les Pyrénées espagnoles, en particulier dans la partie centrale de la chaîne. Les facteurs climatiques et environnementaux sont examinés en détail, ainsi que les réponses géomorphiques à la descente de la limite supérieure des arbres, en particulier entre le seizième et le dix-neuvième siècles. Au cours de cette période, l'expansion du pâturage de bétail a considérablement réduit la converture forestière et a causé une descente sensible de la limite altitudinale inférieure de l'activité périglaciaire. Les formes périglaciaires héritées peuvent être attribuées à la fin de l'ère quaternaire, bien qu'un grand nombre de formes vives soient présentes de nos jours. Ces formes comprennent des coulées de rocailles, des lobes et terrassettes de solifluxion, et différents types de modelés du terrain. Il est démontré que l'altitude, l'exposition, l'inclinaison des versants et la lithologie sont des facteurs déterminants, ainsi que le degré croissant de continentalité dans les Pyrénées centrales, comparé aux zones plus à l'est ou à l'ouest. La région de hautes montagnes est divisée en deux zones altitudinales, le niveau $2.400 \mathrm{~m}$ constituant la ligne de séparation générale.

7usammenfassung Geomorphische Vorgänge oberhalb der Baumgrenze in den spanischen Pyrenäen. Dieser Beitrag gibt eine allgemeine Beschreibung von geomorphischen Vorgängen oberhalb der Baumgrenze in den spanischen Pyrenäen, wobei das Zentralgebiet der Gebirgskette besonders hervorgehoben wird. Klimatische- und Umweltfaktoren werden detailliert erörtert, ebenso die geomorphischen Reaktionen auf das Absinken der oberen Baumgrenze besonders im Zeitraum zwischen dem 16. und 19. Jahrhundert. Während dieser Zeitspanne reduzierte gesteigertes (Vieh-) Weiden die Bewaldung der Hänge nachhaltig, was zu einem beträchtlichen Absinken der unteren Höhengrenze von glazialen Aktivitäten führte. Überreste glazialer Formen werden dem späten Quartär zugeschrieben, obwohl viele aktive Formen auch heute noch vorhanden sind; sie umfassen Gesteinsflüsse, durch langsames Abrutschen des Erdreichs geformte Aufstauungen und Terrassen, sowie verschiedene Arten von Bodenoberflächenstrukturen. Es wird gezeigt, daß in den Zentralpyrenäen Höhe, Lage, Hanggradient und Gesteinsart zusammen mit zunehmenden Änderungen zum Kontinentalklima wichtige Bestimmungsfaktoren sind, wenn man diese Region mit Gebieten vergleicht, die weiter westlich oder östlich davon liegen. Die Hochgebirgsregion wird in zwei Höhengürtel unterteilt, wobei die 2.400 m Höhenlinie die Trennungsgrenze bildet.

RESUMEn Procesos geomorfológicos a nivel supraforestal en el Pirineo Español. El artículo expone un sumario relato sobre Los procesos geomórficos operando a nivel supraforestal en el Pirineo espan̈ol, con especial referencia al sector central de la Corđillera. Se discuten con detalle los factores climáticos y ambientales, tanto como las respuestas geomórficas causa del descenso del límite superior del bosque, especialmente deI XVI al XIX. Durante dicho periodo de acentuada carga ganadera, se redujo la extensión del bosque y se produjo un substancial descenso del límite inferior de la actividad periglaciar. Las formas relictas periglaciares se atribuyen al Cuaternario tardío, no obstante hay todavía hoy formas activas. Entre ellas: glaciares rocosos, lóbulos de soliflucción, terracillas o gradines y varios tipos de suelos poligonales. Altitud, exposición, lo acusado de la pendiente y la litología, son los principales factores, agudizados por la continentalidad en el sector central de la Cordillera y atenuandose hacia ambos extremos oriental y occidental. De forma general cabría concluir que la cota de $2.400 \mathrm{~m}$. S/M., constituye un límite de dos niveles de alta montaña.

${ }^{1}$ Instituto Pirenaico de Ecologia, Apartado 64, Jaca (Huesca), Spain.

${ }^{2}$ Estacion Experimental de Zonas Aridas, c/. General Segura, 04001 Almeria, Spain, 


\section{INTRODUGTION}

The Pyrenees constitute the natural border between France and Spain. Because of their altitude (Aneto Peak, $3,404 \mathrm{~m}$ ) and extent (about $500 \mathrm{~km}$ from the Bay of Biscay to the Cape of Creus on the Mediterranean coast) they cannot be counted among the great mountain chains of the world, such as the Alps or Himalaya. To study these ranges, nevertheless, is of great interest and significance as Altantic and Mediterranean influences merge in the Pyrenees; they have undergone remarkable demographic pressure; and their comparatively high altitude in this latitude $\left(42-43^{\circ} \mathrm{N}\right)$ is responsible for the existence of a tundra belt above timberline which includes small local glaciers. On the lower Pyrenean slopes (from 700 to $1,000 \mathrm{~m}$ ) the subMediterranean belt is notably degraded and only partially cultivated at present. Above this level increasingly wooded environments are found and higher still the forests give way (usually owing to human action) to belts, the dynamics of which depend on snow and freeze-thaw processes and where low temperatures prevail most of the year. This paper will concentrate on this highest level and will discuss the geomorphic processes and the factors that explain the hydromorphic diversity characteristic of the highest Pyrenean altitudes.

Most geomorphic studies on the Pyrenees have been related to glaciation and to research on periglacial phenomena that originated during the last major glaciation (Würm equivalent). Present-day processes have attracted less attention (Llobet, 1975), though this may be due to the frequent claim that they are rare and of little extent (Llobet, 1978-79). However, recent studies show a wide variety of processes in the Pyrenean mid- and highmountain regions (Soutade, 1980; Garcia-Ruiz and Puigdefabregas, 1982) some of which had already been noted by French geomorphologists in the early 1950s (Barrère, 1952; Boyé, 1952). The first compilation of the available data on periglacial geomorphology, limited though it is, has been produced recently by Gonzalez-Martin (1986).

\section{GEOMORPHIC PROCESSES IN THE LATE QUATERNARY}

Numerous deposits resulting from periglacial processes during the Quaternary period can be found throughout the Pyrenees. It is more difficult, however, to observe traces of other types of processes since they are easily destroyed by slight changes of climatic conditions and they do not leave thick deposits that can be correlated throughout the region.

Non-active (or fossil) periglacial features, correspond (at least according to available data) to the period of Würm maximum activity and to later periods. In most cases, it is very difficult to produce an absolute chronology, although the position of each deposit, in a regional topographical context, permits determination of a relative chronological order. Obviously, the lowest deposits coincide with the glacial maximum, the point at which the periglacial climate (characterized by intense freeze-thaw processes) reached its greatest extent. Most probably, coinciding with this maximum, there would be other areas above the glaciers with active periglacial conditions because there was no permanent snow cover due to the high wind factor, as pointed out by Gomez-Ortiz and Serrat (1978) for the Eastern Pyrenees. The evidence for this, however, was mostly erased by subsequent periglacial activity during the Holocene.

The most frequent deposits belong to the stratified scree type (grèzes lités or éboulis ordonnés) generally located at very low levels. Sole-Sugrañes (1973) places the lowest limit at $700 \mathrm{~m}$ in the Eastern Pyrenees, and points out that they belong to the last glacial stage, as they lack the pedological development that would characterize warmer climates. Gomez-Ortiz (1981) observes the presence of comparable deposits at $940 \mathrm{~m}$ altitude, at the foot of slate cliffs. Serrat (1977) also points out the great thickness of Würm stratified screes formed under attenuated periglacial activity with frequent freezing periods. According to Marti-Bono and Gonzalez (1979) some of these deposits are contemporary to the glacial period, while others are clearly postglacial (stratified screes at Sta. Elena, mid-valley Gallego River). Barrère (1956) also gives a postglacial age to some screes; in his opinion they are more frequently found on southern exposures, which could be attributed to a higher frequency of freeze-thaw periods under colder than present climate conditions. Thick alluvial fans occupy a great part of the main valley bottoms and were formed from sediment totally or partially derived from morainic deposits. They appear to have been deposited immediately after the maximum of the last glacial period. Such fans are found, for instance, in the Son Valley, in the Catalonian Pyrenees (Ventura, 1986), and especially in the Central Pyrenees, as pointed out by Barrère (1966), and Garcia-Ruiz and Puigdefabregas (1982) for the Gallego Valley where some alluvial fans are still active today.

The great majority of the deposits studied, therefore, are closely related to freeze-thaw processes on rocky outcrops with sedimentation at the foot after brief transport, sometimes simply as a result of gravity. However, other kinds of deposit are also present, such as the solifluction lobes, 8-10 $\mathrm{m}$ wide, identified by Gimenez (1982) at Turbon Peak in the Central Pyrenees. These are found throughout a broad altitude range (from 1,000 to $1,900 \mathrm{~m}$ ) which also indicates their relevance to an extensive chronological period. In the highest areas remains of relatively recent processes indicate discontinuous permafrost and there are a great number of rock glaciers, clearly postglacial by reason of their topographical situation and, in some cases, active until recently.

At a more detailed level, traces of patterned ground phenomena have been found. Gomez-Ortiz and Serrat (1978) found large polygons at 2,700 $\mathrm{m}$ altitude in the Eastern Pyrenees. They propose that, after the extinction 
of the glaciers, stone stripes and polygons were formed on the floors of cirques unless rock glaciers occurred instead. Soutade (1970a) also has discovered recent polygons on the Gorra Blanc high plateau in the Eastern Pyrcnees, which are at present undergoing degrading processes; their sizes are somewhere between mesopolygons and tundra macropolygons.

Gonzalez-Martin (1986) has observed that most references to non-active periglacial phenomena are centered on the Eastern Pyrenees, so far the most closely studied area. They are found also in the Central Pyrenees where there are numerous deposits at various altitudes. Nevertheless, it is not easy to categorize the processes and deposits, other than debris and rock glaciers; in the morpho-climatically active environment of high mountains, processes are often superimposed and deposits may be transported rapidly downslope into the drainage channels.

\section{ENVIRONMENTAL DIVERSITY IN THE PYRENEAN BELT ABOVE THE TIMBERLINE}

In the past, human action has resulted in extensive changes in the upper forest limit of the Pyrenees. The need to expand the area devoted to summer grazing to feed cattle caused a lowering of the timberline by several hundred meters. It is unusual for forests to be found above $1,800 \mathrm{~m}$ and pasture lands in degraded forests begin at $1,500-1,600 \mathrm{~m}$. However, some isolated individuals of Pinus Uncinata occur slightly above 2,200 $\mathrm{m}$ in the Central Pyrenees. There is an abrupt lowering of the timberline on certain slopes that is not related to changes in environmental conditions. This has caused a great increase in the extent of grassland and alpine meadow on the highest slopes and a corresponding reduction in the area of forest.

Such a phenomenon is rather common in the European mountains that are under the strong pressure of stockraising. The consequences affect not only the landscape and land use. Hollermann (1985) considers that, under natural conditions, the altitudinal change from forest to pasture indicates a change in morphodynamic system: in other words, the domain of active solifluction is extended and the role played by the forest cover reduced (this is related to elimination of root systems, interception of precipitation, protective surface against low temperatures which render the forest environment much less susceptible to geomorphical activity). The reduction in the altitude of the timberline by human impact has resulted in a progressive lowering of the lower limit of solifluction. Hollermann (1985) indicates that frost action rnanifests itself even $400 \mathrm{~m}$ below the natural timberline. Therefore, partially at least, the natural processes in the belt above the timberline have been extended to lower altitudes where they cause a notable increase in slope instability.

Above the forest limit, the different processes appear spatially distributed in a pattern determined by the environmental diversity of mountain regions. Within relatively short distances, all topographic, pedologic, and hydrologic conditions, and even the thermal regime may change. According to Hollermann (1985) the controlling factors in the distribution of periglacial processes are: climate, as the main factor, partially from a thermal point of view; substratum and soil moisture (closely related to topography); and human impact. To these should be added the possible role played by burrowing animals and its influence on the movements of ground water. It is also necessary to include the geomorphic importance of deep soils.

In the Pyrenees the alpine belt, or the area above treeline, is limited to the central and east-central sections, where the highest elevations occur, frequently surpassing 3,000 m. Eastward and westward elevations decrease progressively and, strictly speaking, active high mountain geomorphic processes do not occur. This central area is quite isolated from both Atlantic and Mediterranean influences and exhibits some continental features: decrease of winter precipitation and increase in late spring precipitation. In addition, the winter isotherm of $0^{\circ} \mathrm{C}$ (which indicates the altitude above which snow accumulates in the cold season) is inclined from west to east. Thus, GarciaRuiz, Puigdefabregas and Creus (1985) calculated that the $0^{\circ} \mathrm{C}$ isotherm position was at $1,549 \mathrm{~m}$ altitude in the Aragon River valley, at 1,635 $\mathrm{m}$ in the Gallego Valley, and at $1,700 \mathrm{~m}$ in the Esera Valley. These altitudes coincide closely with the level where today, with few exceptions, pastures above the timberline begin. They also correlate with the elevation of the Würm glacial moraines in the various valleys and indicate the former existence of thermal gradients from east to west; initially there is an increase of continentality upon which the Mediterranean influence is superimposed with increasing distance toward the east. Nevertheless, because of the lower altitude and extent of high land, the melt season ends earlier in the Western and Eastern Pyrenees than in the central region where it lasts until the end of June. This is confirmed by the study of river discharge peaks in the main rivers (Garcia-Ruiz, Puigdefabregas, and Creus, 1986).

Another important aspect is the different behavior pattern of snow melt as it relates to topography and to humidity and aridity. On southern slopes, melting takes place very early; even in mid-winter, snowfalls are followed by rapid melting which causes the soil to become saturated. Therefore, southern slopes constitute highly unstable environments subject to changes ranging from periods of ground freezing and saturation from melt-water to periods of snow cover. In contrast, conditions on northern slopes are much more stable because of the permanent protection of the snow cover during the cold season. Convex slopes suffer intense freezing processes and sudden changes of temperature, as well as retaining much less moisture, Concavities, in contrast, accumulate great masses of snow and are typified by cold microclimatic conditions: this creates super-saturated environments. In this case, topography is a major factor that determines slope dynamics at the microscale since it conditions the spatial organization of moisture and water movement, and also the rate of downslope transport of the surface mantle.

A third factor influencing the diversity and control of 
Landslides on hillslopes with deep soils; they consist of semi-circular fractures with an irregular lobe at the foot (Sierra de Otal, Central Pyrenees).

Terracettes in the upper part of Ordesa National Park; they are secondary forms over a $\mathrm{C}$ horizon of eroded soils.

Gully erosion at the base of hillslopes in the Aisa Valley several centuries after deforestation.
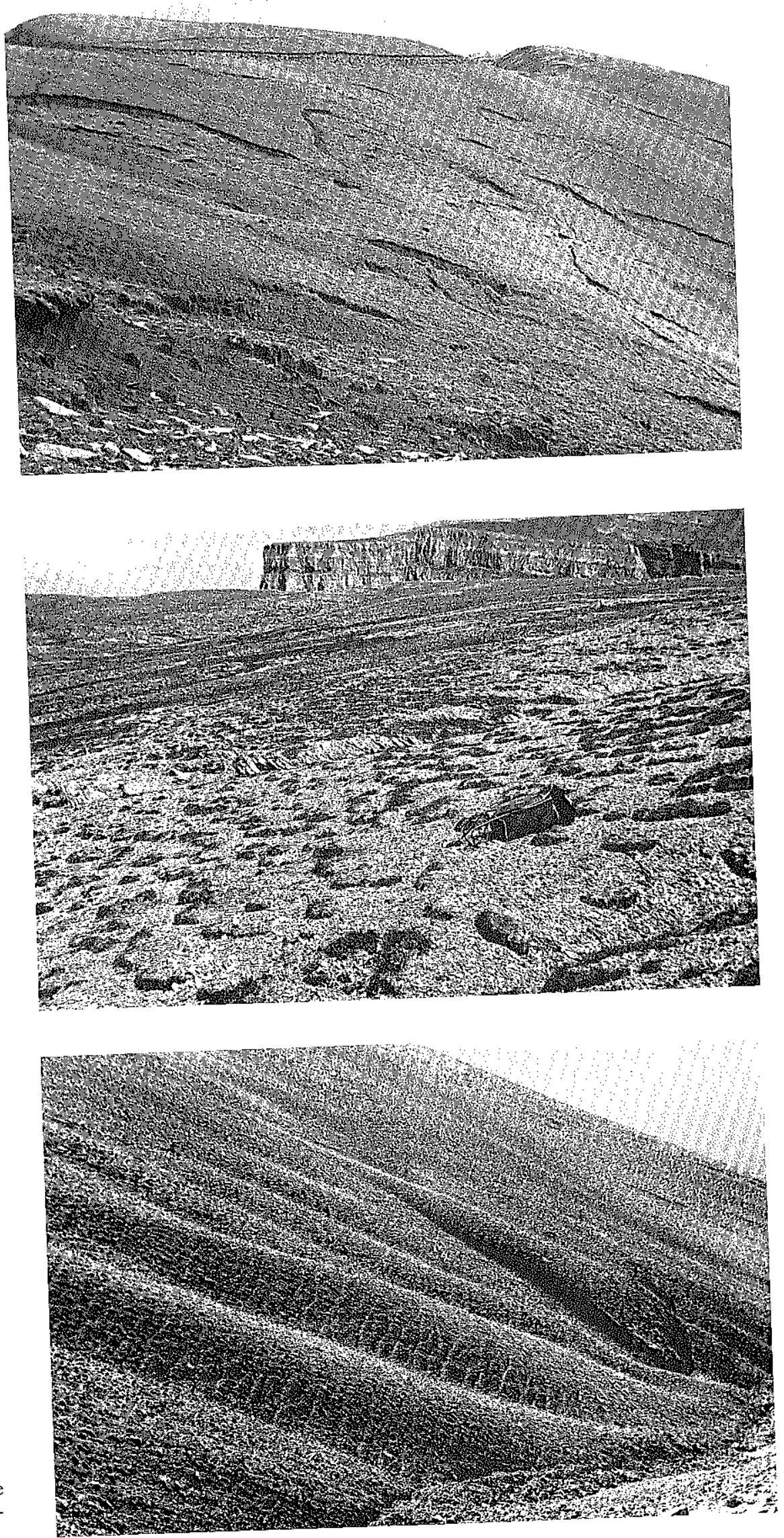


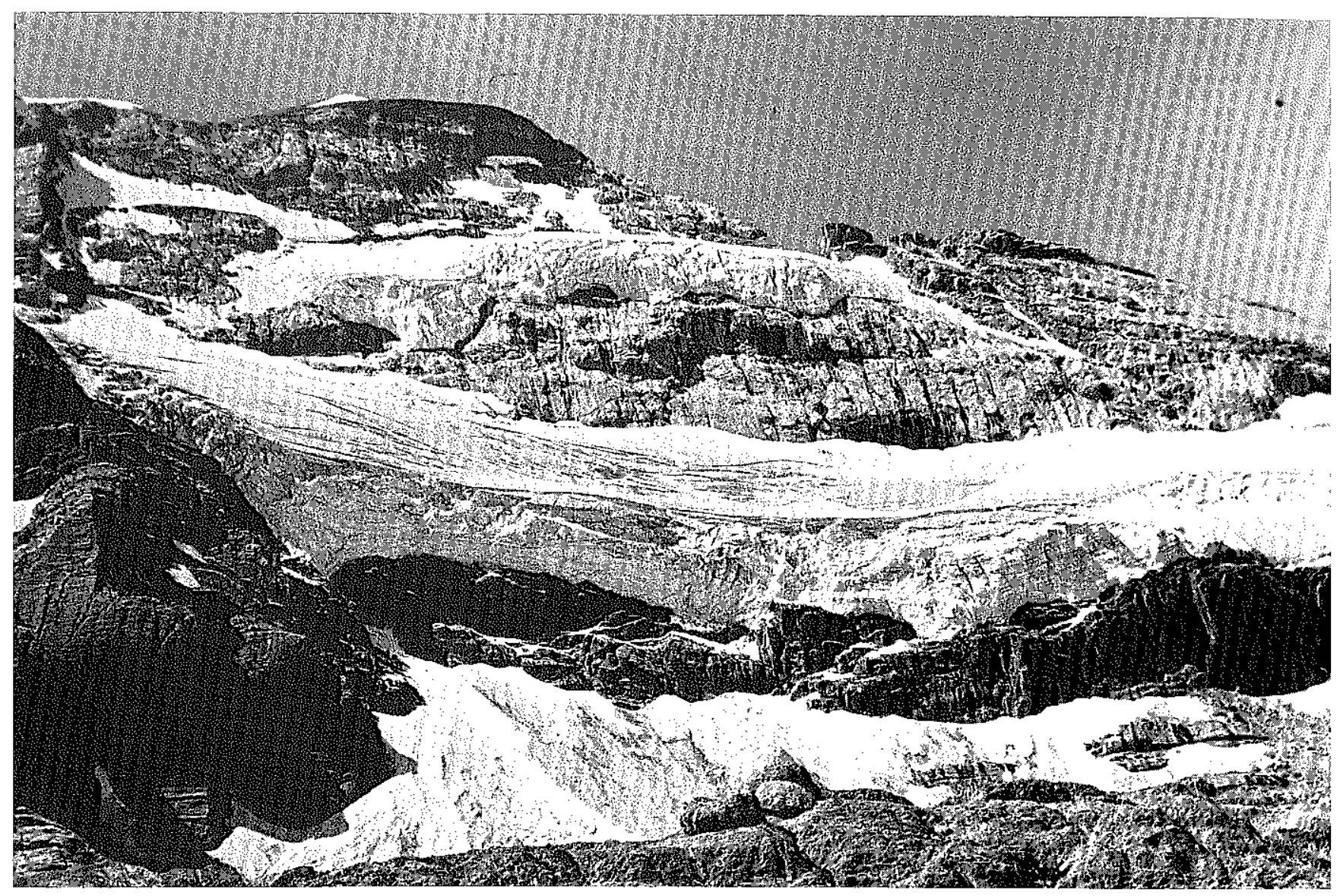

The Monte Perdido Glacier in Ordesa National Park; the glacier has retreated significantly in the last thirty years and has divided into two small ice masses.

geomorphic processes is lithology. Hollermann (1967) and Brosch (1978) have pointed out that different periglacial forms depend on the type of underlying rock, and particularly on the depth and texture of the soils that form. Soutade (1980) also used lithology to explain the spatial distribution of morphodynamic features in the Western Pyrenees. Throughout the Pyrenees the gcomorphic processes vary with rock type-flysch, limestones, granites, slates, and schists can each be identified (under relatively similar climatic conditions) by the prevalence of the geomorphic processes that are associated with the particular morphoclimatic systems.

It is lithology that is the main explanation for the presence or absence of deep soils which are very frequent in the Pyrenees on flysch, loamy limestones, and slates, especially above $1,400 \mathrm{~m}$, and are clearly absent on granites and pure limestones. They are well-structured soils, rich in organic matter, with good permeability; they contain a high proportion of sand $(40-50 \%)$, their $\mathrm{pH}$ is close to 5, and they lack carbonates (Garcia Viñao et al. 1986). These soils frequently reach a thickness of $50 \mathrm{~cm}$. Owing to their peculiar properties they have a considerable influence on slope dynamics. Their distribution also depends partially on topography since they are absent on gradients of over 30 degrees (Puigdefabregas and Garcia* Ruiz, 1983) and are thickest at the base of slopes and on flat terrace surfaces.

In such a heterogeneous environment, in which exposure, gradient, lithology, land use, and presence of deep soils constitute a highly complex mosaic, altitude plays a predominant role. Some authors use an altitude criterium (which is actually a thermal criterium) to differentiate sections within periglacial systems. Hence, Soutade (1976) notes that in the Puigmal massif (Eastern Pyrenees) there is a threshold at about $1,500 \mathrm{~m}$ above which cryonival processes prevail over surface-wash processes; that is, a limit that separates purely periglacial processes from those which include processes of humid and less cold climates.

Hollermann (1985) distinguishes two belts above the timberiine: a) an active solifluction belt, with its lower limit immediately above the timberline, formed mainly by solifluction lobes and terracettes and generally occupied by pastures; b) an upper belt of solifluction and patterned ground, where blockfields, screes, and stone pavements (dallages) are predominant, and with extensive areas of bare ground. In some sectors, it is usual to find that the 
Patterned ground on the Monte Perdido massif close to the glacier; in flat, wet areas there are floating polygons.
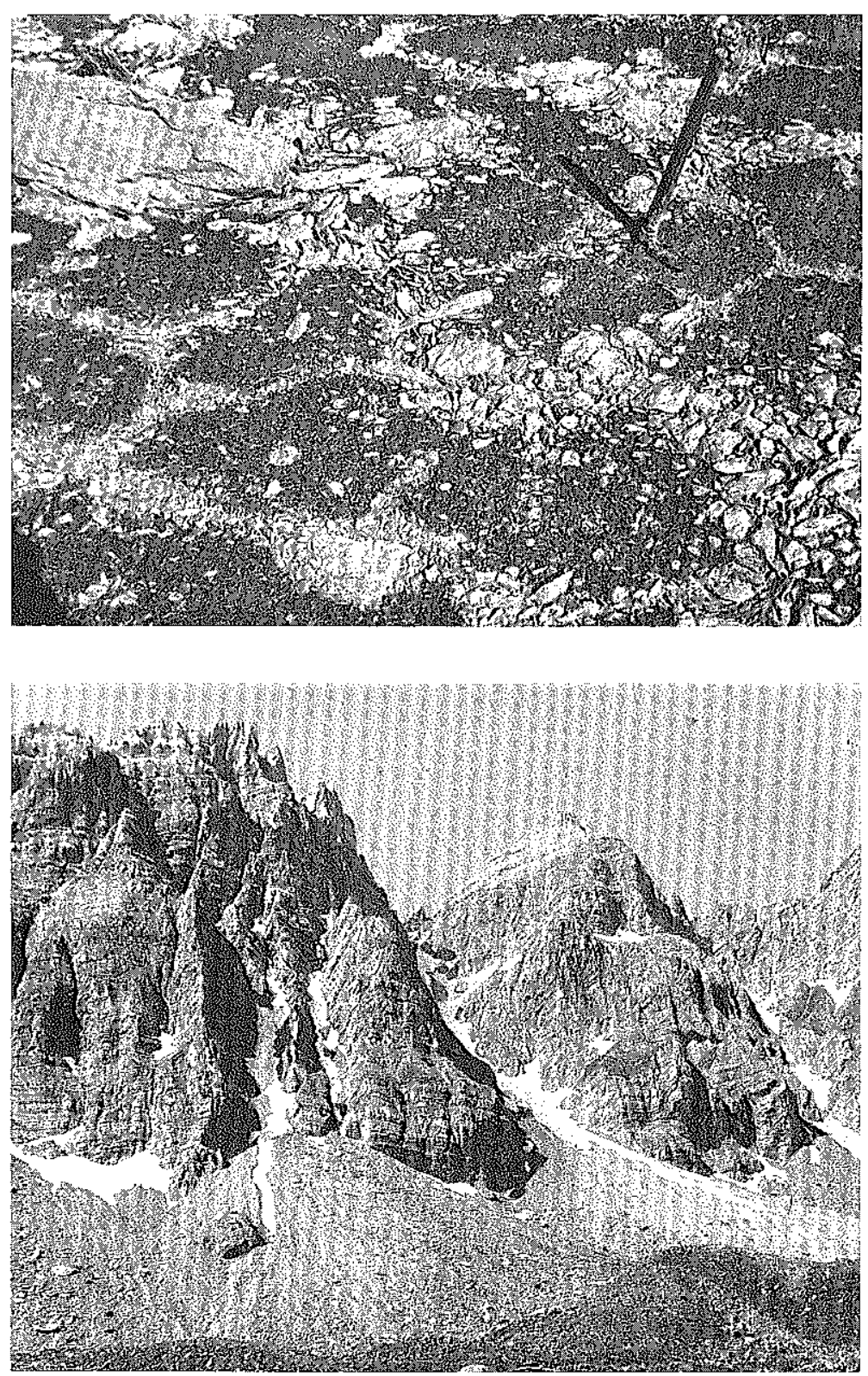

A rock wall affected by gelifraction and snow avalanches on the northern face of the Inner Sicrra in the Central Pyrenees. porary dryness; and (iv) rocky bluffs.

Altitude criterium has been used in this study and several processes are differential according to soil type and topography. In this way those processes with mass movement and runoff of different origins are distinguished from those that occur in the high mountain belt where snow and ice are the dominant control forces.

\section{GEOMORPHIC PROCESSES IN THE MID-ALTITUDE PYRENEAN RANGE}

Lower and upper limits of different types of geomorphic activity are difficult to determine in these middle elevation environments. The lower limit depends primarily on the altitude of the forest belt; the upper limit appears closely related to topographic diversity and lies at about 2,400 m owing to the higher frequency above this level of those prom cesses and forms related to frost and snow action. In the lower periglacial belt mass wasting processes of different 
magnitudes and other processes related to surface wash are the prevalent phenomena. The distribution of both types of process is determined by the presence or absence of deep soils which control solifluction and surface wash as the main systems of sediment transport. In fact, the distribution of forms and processes is not organized according to altitude in this belt (Del Barrio and Puigdefabregas, 1987) but according to slope position which determines soil distribution and thickness. Figure 1 separates those processes occurring on the upper part of the slopes (stone-banked lobes and terracettes) from those characteristic of lower positions (turf-banked lobes, landslides, plowing blocks) that are also related to regolith features.

\section{Progesses on Slopes with Deep Solls}

Where deep soil overlies rock substrates, there is a tendency for infiltration of precipitation to prevail over surface runoff. Evidence of surface runoff is very rare since mass movements obstruct the formation of incipient drainage channels. Mass movement predominates because of the greater depth of soils on the slope and the presence of a strong concentration of seasonal moisture availability: the spring precipitation maximum is augmented by snow-melt runoff, and even some of the sunny slopes become saturated from mid-winter onward because of the high frequency of successive melt and snow periods. In these environments there are landslides, solifluction lobes, massive mudflows, and plowing blocks. Some gel- ifluction lobes can be found locally very near the upper periglacial belt. Each of these forms can be found in different topographic situations.

Landslides are the prevailing feature when slopes with deep soils are disturbed. They are more frequent on sunny exposures and on rectilinear slopes. The landslide scars usually consist of a semicircular niche of various dimensions $(1-10 \mathrm{~m}$ ) limited by a scarp about $40 \mathrm{~cm}$ high (Figure 2). At the toe of the landslide, an irregular lobe can usually be observed. Sometimes, a succession of landslides appear interconnected along the gradient, favored by water accumulation that developed in the uppermost section. In other cases, the form of the landslide scar develops by expanding laterally or headward because of niche collapse. These forms may evolve until wide areas of slope are stripped (Puigdefabregas and Garcia-Ruiz, 1984). Mechanical tests made on such soils show friction angles with little variability $\left(30.3^{\circ} \pm 1.3^{\circ}\right.$ ) (Puigdefabregas and GarciaRuiz, 1983). Starting with the hypothesis of a planar landslide on an infinite slope (Van Asch, 1980), it is suggested that slopes of over 30 degrees are unstable even when the soil mantle is dry, while those less than 15 degrees are stable even when saturated. Practical field observations allow the conclusion that slopes of more than 30 degrees have incurred extensive mass movement and the great majority of the most recent landslides have released on slopes with gradients between 20 and 30 degrees (Garcia-Ruiz and Puigdefabregas, 1984).

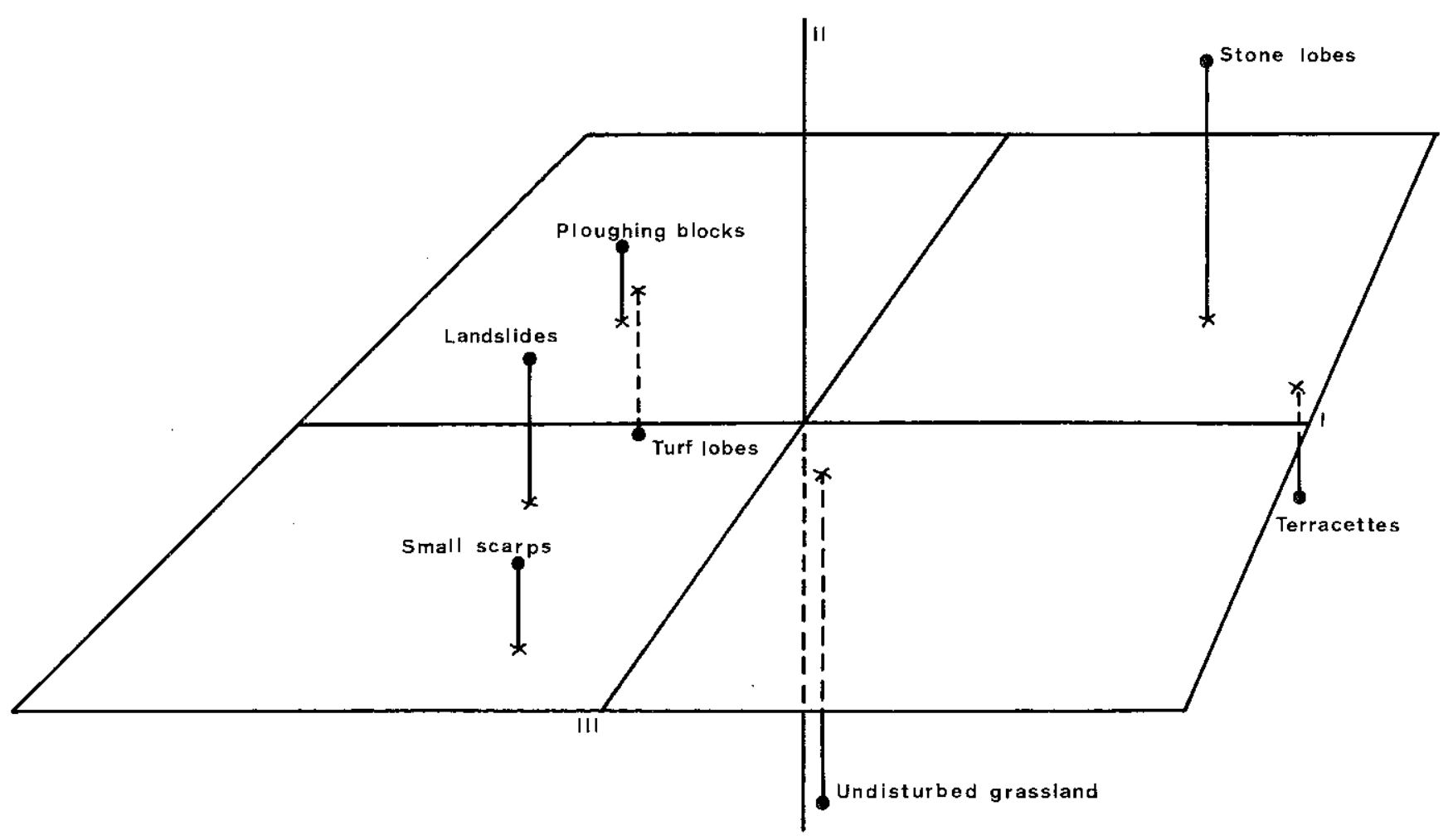

Figure: Landforms plotted by factor scores on Factors 1, 2, and 3 of Q-mode BDA (from Del Barrio and Puigdefabregas, 1987). 


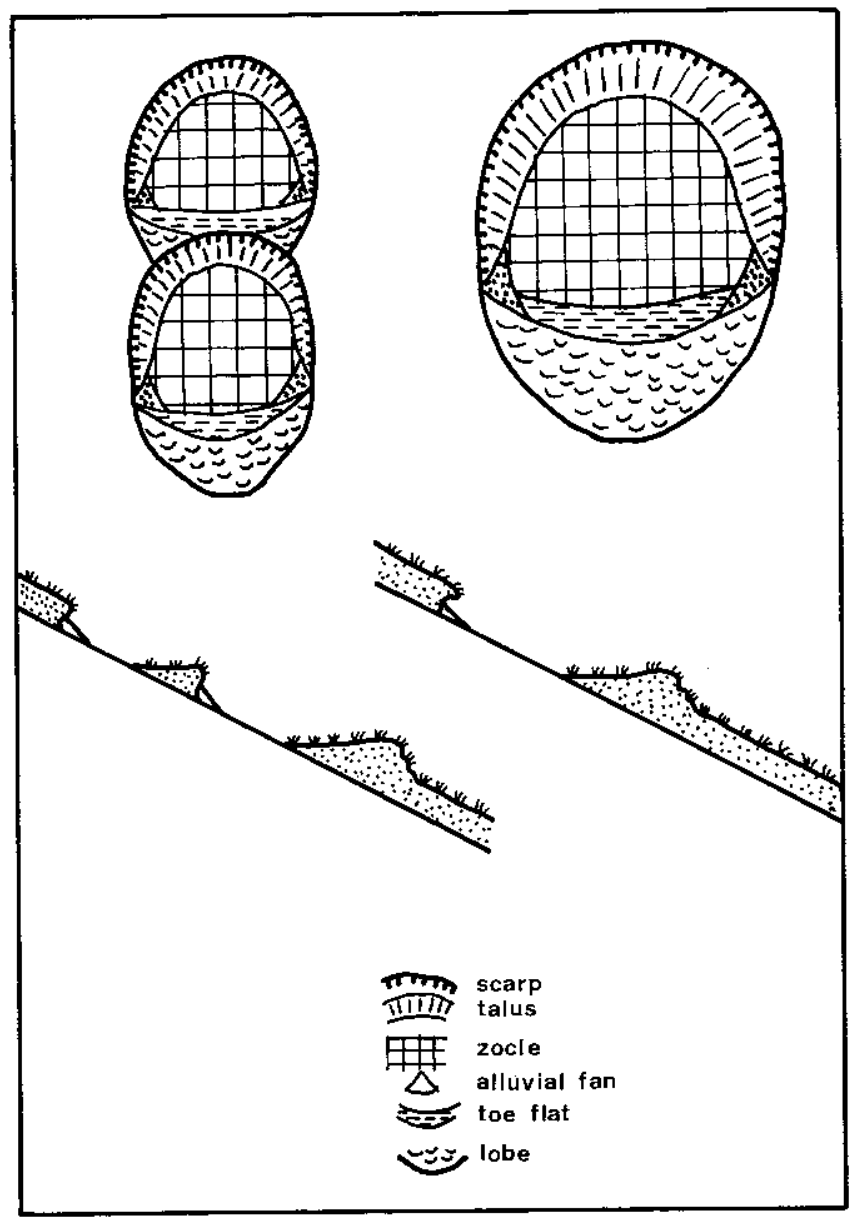

Figure 2. Patterns of slides in the Central Pyrenees.

Owing to their location on formerly wooded slopes, the recent expansion of these phenomena can be attributed directly to deforestation: none is found within the existing forest limits. Garcia-Ruiz and Puigdefabregas (1984) also point out the possibility of a peak of landsliding between the sixteenth and eighteenth centuries, which would coincide with the beginning of a more humid climatic period than the present one (Creus and Puigdefabregas, 1976) and also with the maximum expansion of Pyrenean livestock grazing. Forest devastation would be responsible for the destabilization of slopes and for the change in ground thermal regime. Ice lenses would remain until late spring, while the flow of melt water would occur in the sandy layers under the surface. This would increase hydrostatic pressure and may have caused local ruptures that produced landslides. Garcia Viñao et al. (1986) and Puigdefabregas and Garcia-Ruiz (1984) conclude that landslides lead to a greater diversification of herbaceous communities because of the variety of microenvironments they create. They also become a soil rejuvenating agent since they expose subsurface materials.

Successive landslides, together with other slower moving processes such as soil creep, have caused important regolith accumulations at the foot of slopes and on perched flats. Such environments also receive, in addition to surface and subsurface moisture from higher areas, increasing ground moisture. This is where the best examples of solifluction lobes are formed, some of them showing very little activity while others are completely active. In summary, solifluction adopts two main forms: lobes of various sizes, sometimes lengthened downslope with a distinctive convex front; and less well defined mantles which affect wide areas, such as those at the base of Sierra Custodia (Monte Perdido Massif).

According to Hollermann (1967) the lower limit of solifluction is at present about 2,400 $\mathrm{m}$ in the Eastern Pyrenees, although Sole Sugrañes (1973) places it at $2,100-2,200 \mathrm{~m}$ based on evidence related to climate and especially to geomorphology. However, Creus and GarciaRuiz (1977) point out the existence of active lobes at $1,800 \mathrm{~m}$ in the upper Gallego River valley of the Central Pyrenees. Measurements taken in this environment show the importance of two factors: regolith water content and clay proportion in each lobe displacement. Most annual movements (estimated to average $40 \mathrm{~mm}$ ) take place in spring and coincide with the melting of snow and ice lenses in the ground. The most active lobes are also those that accumulate the greatest amount of water and remain saturated for the longest period of time. Such an apparently important variant as gradient becomes subordinated to the effect of moisture content. Other field scientists also insist on the importance of the substrate as it acts as a control factor on regolith mechanical and hydrological properties. Hence, Gutierrez and Peña (1981) relate solifluction only to slopes weathered in slates of Cambrian-Ordovician age for the area of Bonaigua. In the Central Pyrenees, the best examples are also found over bedrock of slates and schists.

One of the most spectacular areas of extensive mass movement is located in the upper Gallego River valley in the Central Pyrenees (Figure 3), where great slumps and slow-moving mudflows have formed on very fragmented Paleozoic slates. Some of these forms show no activity, though they are certainly recent, while others are active. Sometimes they are more than a kilometer long and appear on all exposures since they have very deep sliding planes. At the time of their formation they have very little speed and a slow plastic motion since they preserve the tongue shape quite well, and they never completely reach the main drainage channel of the Gallego River.

Plowing blocks appear associated with solifluction lobes. Most are active at present and show a remarkable convexity at the front and a linear depression upslope. Yet they appear on major gradients dominated by sandstone cornices which provide large-sized blocks.

The first gelifluction lobes are located very near the upper limit of this belt and do not necessarily need deep soils. They contain a large proportion of periglacial clasts within a fine-grained matrix. Llobet (1975) places them on schist substrates, and Soutade (1976) has found them on the Puigmal Massif (Eastern Pyrenees), at 2,300 m (on south and west-facing slopes), and at $2,400 \mathrm{~m}$ (on north-facing slopes) with no interference of vegetation at this altitude. Apart from mass wasting, which is the most evident transport system where deep soils occur, a significant propor- 


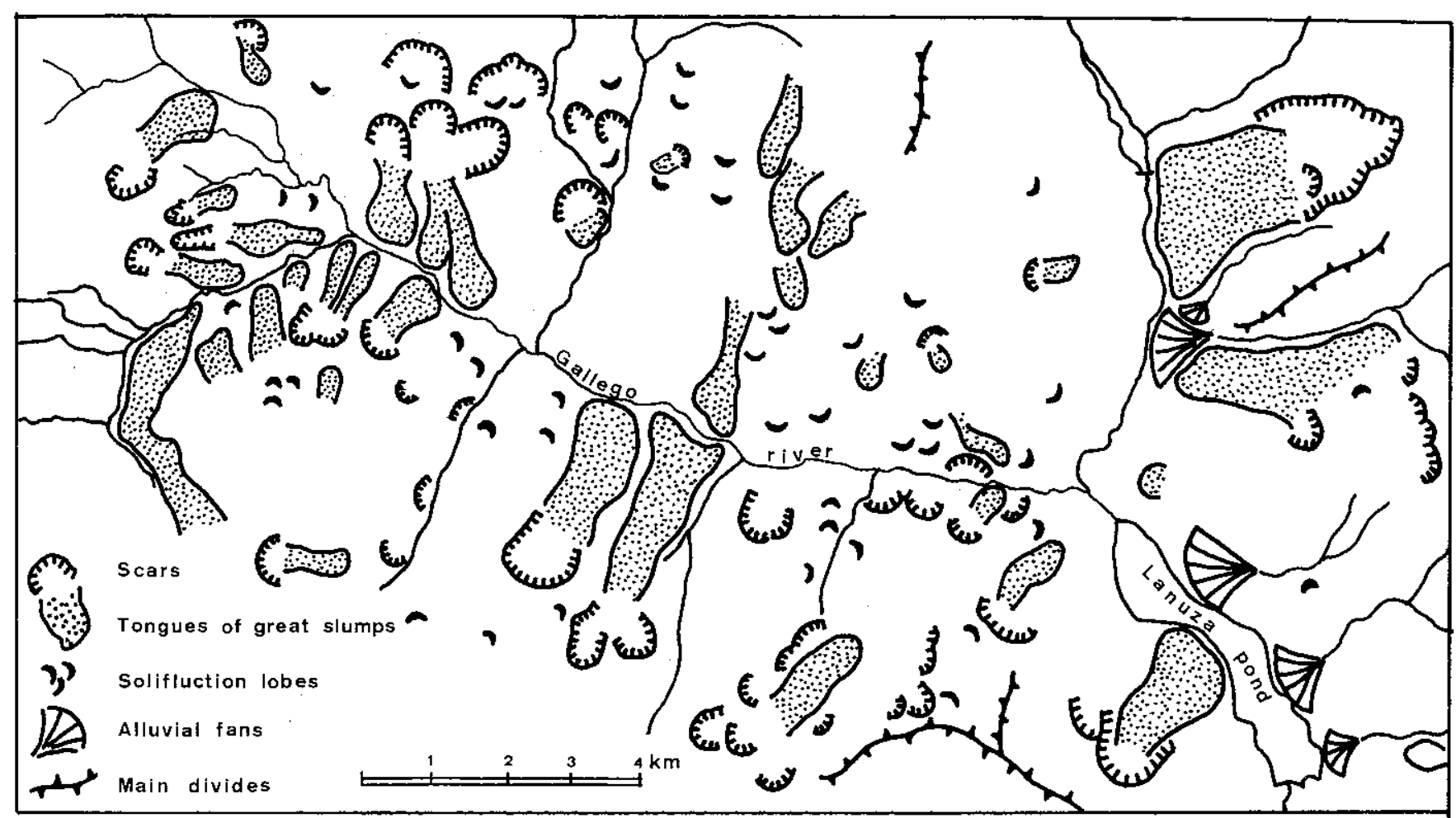

Figure 3. Great mass movements in the high Gallego Valley.

tion of sediment transfer is achieved by runoff waters. Several river basins were studied in the Central Pyrenees. The behavior of solid materials in suspension was analyzed, together with that of several dissolved elements, throughout the year and on melting days, under various land-use conditions (Lavandier and Mur, 1974; Alvera and Puigdefabregas, 1985; Garcia Viñao et al. 1986). The results provide information on variations in runoff and sediment transport and confirm the peculiar character of deep soils above the timberline.

A primary conclusion, of great general interest, is that solute concentration decreases with altitude. Such a phenomenon is probably related to the fact that temperature decrease results in a reduction of the intensity of biological and chemical processes. At the same time there is also an increase in precipitation and runoff related to altitude. The combination of both runoff and solute concentration is the reason why the largest outputs of materials in solution occur mainly at middle elevations, close to $1,500 \mathrm{~m}$ (Figure 4).

Solute concentration in lime substrates (flysch) shows no major change throughout the year. However, some elements such as calcium, sodium, and potassium are diluted during the melt season, while phosphorous concentration increases together with the other elements in suspension. This effect is caused by the prevalence of overland flow during the melt period when soils are saturated and/or superficially frozen which enriches them with nutrients, litter, and humus (as in the case of phosphorous) and with sediments from the slopes of the drainage channel during peak flows. Under such conditions infiltration is less im- portant and nutrients, with sources in the mineral layer and the substrate, become diluted (as in the case of calcium and sodium). At the end of the melt season, when there are isolated snow patches and unfrozen soils, infiltration prevails and phosphorous concentration decreases. This

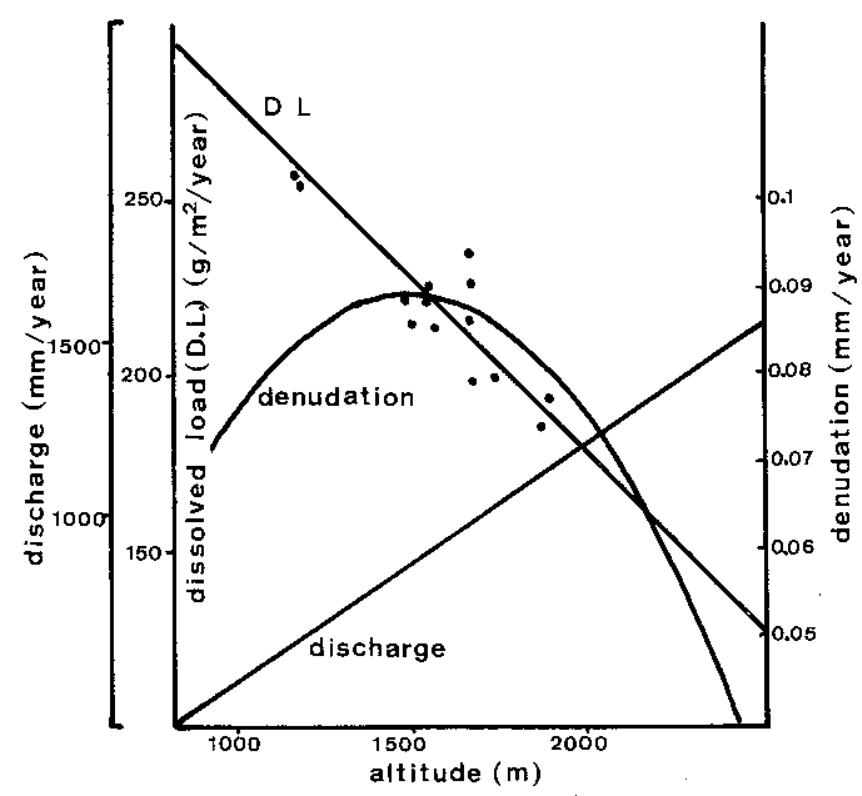

FigURE 4. Evaluation of the altitudinal behavior of denudation, dissolved load, and discharge in the high basins of the Aragon and Gallego rivers (from Puigdefabregas and Alvera, 1986a). 
stage of the melt season is of greatest hydrologic and geomorphic importance since 50 percent of water output and material transport (either dissolved or in suspension) occurs at this time. The remaining 50 percent is removed in autumn and winter. These processes are inactive during summer. From the available data it can be deduced that the transport of solutes is ten times greater than the transport of solids in suspension ( $15 \mathrm{mg} / \mathrm{l}$ vs. $155 \mathrm{mg} / \mathrm{l}$ ). However it has not been possible, so far, to obtain data from peak flows on days of torrential rain in autumn when great amounts of material in suspension might be transported. At the Lubierre River headwaters the annual average solute discharge has been estimated at $606 \mathrm{~kg} / \mathrm{ha}$.

A progressive decrease in all solute materials can be observed in siliceous substrates during the melt season (Puigdefabregas and Alvera, 1986b). This may indicate depletion of mineral supplies recovered in the biologically active season of summer through autumn. Lavandier and Mur (1974) do not record such a reduction in the granite basins in the French Pyrenees where most mineral element concentrations are diluted during peak flows.

Important changes in solute concentration have been observed during daily analysis. Those originating in mineral soil and substrate lixiviation are diluted during peak flows. Slightly before peak flow, sediments increase; their origin is found close to the completely saturated snow-melt front and in small talus deposits across the river bed (Leonard et al. 1979). Phosphorous shows a different behavior; Lavandier and Mur (1974) and Leonard et al. (1979) suggest that precipitation is one of the main sources of dissolved phosphorous which is retained in the soil when infiltration prevails and is released when overland flow predominates.

Sediment evacuation depends greatly on topography and on the type of land use. Hence, Alvera and Puigdefabregas (1985), while analyzing the drainage structure along a straight slope with a concavity at its base, observed that the highest nitrate concentrations appeared in the upper part near the water input and that such concentrations were reduced by a factor of 4 at the outlet of the saturated concave basal area. This reduction may be related to the absorption of nitrates by benthic weeds or to a bacterial denitrification. Garcia Viñao et al. (1986) point out that basal concavities act as partial contribution areas. They are saturated by subsurface water circulation and become the main source of sediments in suspension. Alvera and Puigdefabregas (1985) corroborate the observation that saturated areas may provide ten times more sediment per surface unit than uppermost slope areas, provided there is a well developed soil mantle.

Deforestation also causes a considerable increase in runoff and sediment transfer. A comparison was made between two river basins of similar substrate, altitude, gradient, and orientation in the Central Pyrenees by the Instituto Pirenaico de Ecología (unpublished data). One basin included pastures above the forest, the other was entirely in dense forest of Pinus sylvestris and $P$. uncinata. The average runoff from the pastures $\left(12.91 / \mathrm{s} / \mathrm{km}^{2}\right)$ is twice that from the forest $\left(6.2 \mathrm{I} / \mathrm{s} / \mathrm{km}^{2}\right)$. Sediments in suspension are ten times greater in areas under pasture. These results show how strongly the hydromorphic behavior of formerly wooded slopes has been altered. On these slopes, now used as pastures, an increase in mass movement and sediment transfer (linked to the increased runoff) has been demonstrated. Land-use influence is also corroborated by studies carried out on the effects of the construction of winter sports resorts on sediment transport. The Astun basin where one winter resort is located and the Canal Roya basin which is used traditionally as pasture land in summer have been compared. Concentration of sediments is seven times higher in the Astun basin than in the undisturbed basin; the difference increases up to 22 times in summer when the severely degraded areas are not protected by a snow cover.

\section{Processes on Slopes with Thin Solls}

On those slopes with a gradient in excess of 30 degrees, deep soils have been removed. Geomorphic processes, therefore, are very different since surface runoff prevails over infiltration. Under such conditions a wide variety of processes take place from surface mass movement on the remaining regolith to the spectacular formation of rill and gully systems.

Terracettes are widespread throughout the Pyrenees, generally as secondary forms over the C-horizon of already eroded slopes where there is still some infiltration capacity and rill formation is not yet well developed. Because the regolith remains limited these slopes become saturated very easily. This includes mass movements downslope, particularly during the melt season and when thermal changes cause ground contraction and expansion. The sliding movement is very slow and consequently a very peculiar type of vegetation cover is produced. The terrace treads are vegetated while the steps (generally as steep as the slope itself) appear without cover. The annual movement causes the treads with vegetation to become progressively buried by the materials descending from the steps. According to Brosche (1978) this process could be a solifluction phenomenon, retarded or retained by vegetation (gehemte solifluktion). This kind of movement appears normal in areas where melting takes place early, a fact recognized by Soutade (1980) on straight or convex slopes but never on concavities where soil accumulation is relatively greater. Brosche (1978) finds terracettes mainly on slate clays, and Soutade (1970) finds them on gneiss banks containing great quantities of kaolin, although what is really necessary for their best development is a substrate that is slightly loamy.

It is important to distinguish between Festuca eskia and $F$. gautieri terracettes. The former tend to occur on the leeward side where the melt season is prolonged until the end of the spring making it too late in the year for freeze-thaw processes to have any significance. The latter are oriented northwest, exposed to the prevailing wind. In such environments there is no significant snow accumulation and freeze-thaw dynamics are very active. Moreover, this type of terracette covers a broad topographical spectrum. Terracettes are accompanied by movement of surface material, which can develop into small stone lobes. On gradients in excess of 20-25 degrees, terracettes become more widely 
spaced, they have a very small tread, and are progressively buried by coarse materials moving downslope. On the average, $F$. gautieri terracettes are smaller $(0.7 \mathrm{~m}$ wide vs. $1.3 \mathrm{~m}$ for $F$. eskia) and are more active.

On other areas similar to those where terracettes have formed, stone-banked lobes are frequently found, usually on the upper slopes. They develop on steep gradients with a windward exposure, and need rocky outcrops as a source of materials although these may be quite small. On such slopes Festuca gautieri is predominant and appears limited to very narrow strips between which stone lobes have developed parallel to each other, particularly if the lobe dimensions are relatively large $(8.5 \mathrm{~m}$ length $\times 1.2$ width $\times 0.3$ thick). If they are smaller $(1.5 \times 0.5 \times 0.15 \mathrm{~m})$, terracette movement is restricted and lobes move down among them.

Terracettes and stone-banked lobes are the most characteristic mass wasting forms on slopes without deep soils. Other processes are mainly related to runoff on very steep slopes where infiltration is rare and the speed of water flow increases with slope facet length. The active headwaters of ravines, rills, and poorly integrated gullies typify these conditions.

Active headwaters are always located on gradients in excess of 50 degrees and even steeper, with xerophitic pasture or bare rocks, on north, northwest, and northeast exposures (Garcia-Ruiz and Puigdefabregas, 1982). They are important sediment sources, and move quickly into the main channels. They contain great quantities of unsorted surface stones, alternating with terracettes, mud-flows, and small debris flows. Some of these headwaters are well developed, but others form mere concave hollows which act rather as partial contribution areas than as major sediment sources. Yet, when they reach the base of the slope they generally form small but very active alluvial fans. Occasionally, the headwaters of the ravines are very recent, the result of an intensive rainfall event. For example, at Canigó (Soutade, 1980) one intense storm had remarkable effects on the landscape.

Near crestlines, slopes frequently display a very dense drainage network. In places, generally on the upper sections of slopes, remnants of the original edaphic cover are preserved. Immediately below, there is a dense network of rectilinear rills which never become completely integrated into an organized system. These are shallow, parallel cuts and remnants of the original surface have been preserved between the channels.

The steepness and rectilinear shape of the slopes explain why overland flow does not form a hierarchical network; on the other hand, the drainage network is relatively recent and there has been no time for development of an organized system. Sometimes rills begin at the foot of small scarps where snow patches remain until summer and where slopes receive great amounts of water which cannot totally infiltrate. Their equilibrium under present climatic conditions is rather uncertain for there are young pines within the drainage lines and a break of slope where they join the main fluvial channel. Some slopes of this type seem to evolve by forming micro-rills which are periodically destroyed because of terracette dynamics, thus blocking the formation of deeper incisions into the surface. Garcia-Ruiz and Puigdefabregas (1982) also have suggested the possible influence of subsurface runoff in the initial formation of rills. On the lower section of slopes some rills become fairly large gullies. The change to badlands is very rare and is possible only locally in slate or clay substrates, for example in the Escarra Valley (upper Gallego Province) or on the Permo-triassic substrates of the Aragon Subordan headwaters.

Frequently, sheet wash does not result in formation of a drainage net. On stony slopes where soil has been removed, sheet wash is prevalent, but is partially diverted and disrupted by blocks. The slopes maintain their rectilinear shape but soil is lost and the number of surface stones increases. This makes terracette formation difficult because of the heterogeneous size of the material. Sheet wash on such features is limited to the upper part of the slope, close to the divide, and on steep gradients, especially in flysch substrate.

\section{GEOMORPHIC PROCESSES AND LANDFORMS IN THE HIGH MOUNTAIN BELT}

Above 2,400 $\mathrm{m}$ the landscape is increasingly dominated by snow cover duration and freeze-thaw intensity, at a daily and seasonal level. Precipitation occurs mainly in solid form or onto a snow cover; only those precipitation events that occur at the beginning of autumn, or as summer storms, fall directly on the ground and have an erosive effect. It is generally an environment under the control of cyronival processes, softened by a seasonal pluviometric regime. However, there are generally no well-developed soils. At most there are stony deposits with a sandy matrix, poor in clay. Climatic conditions ensure the predominance of mechanical weathering.

The most consistent process in the Pyrenean high mountain region is the formation of talus slopes by the accumulation of heterometric clasts at the foot of rock scarps. Other processes are more local and less frequent, generally depending on special topographic conditions. Talus slopes, therefore, are the most extensive forms in the upper periglacial belt, although they are not found exclusively in cold environments. Below 2,400 m they occur frequently where there are rocky outcrops and strong thermal temperature fluctuations; some exhibit an incipient colonization of vegetation but they are not as spectacular as those at the higher elevations.

The most active talus appears to be related to a particular rock type (mainly limestone and, less frequently, granite which produces smaller accumulations) and to particular landforms, such as glacial cirque walls and fault scarps. Because there are no extensive rock outcrops deposits are few and of limited extent, however favorable the climatic conditions may be. Allee (1984) has pointed out that in Haut Vallespir (Eastern Pyrenees), debris formation is more common below $1,700-1,800 \mathrm{~m}$, due to the lithology and topography. In the Central Pyrenees the best 
examples appear between 2,000 and 2,800 $\mathrm{m}$ on the limestones of the Inner Ranges, where they sometimes constitute a continuous slope foot. They can develop on any exposure, although altitude seems to be a decisive factor; between 2,000 and 2,600 $\mathrm{m}$ on north-facing slopes the most active and best developed taluses occur while those with southern exposure at these altitudes show the beginnings of vegetation cover. Above 2,600 m, south-facing talus slopes are very well developed and active; those facing north are generally much smaller. This is due to the efficiency of the freeze-thaw processes since, at high altitudes on north-facing slopes the freeze-thaw threshold is a seasonal factor rather than diurnal, while on southern exposures freeze-thaw activity has a daily rhythm in both spring and autumn.

The development of some talus slopes is influenced by avalanche chutes, which occur along the lines of weakness of the great limestone scarps. In this case their shapes become similar to that of alluvial fans, with steeper gradients and an inverted stratification. This indicates the effects of gravity on their formation.

Talus slopes often nearly merge with protalus ramparts, which obviously were formed earlier. From this it can be concluded that protalus ramparts correspond to a colder stage when ice and snow patches gave rise to moraine-like accumulations at their base; at a later stage the snow patches disappeared and were replaced by debris accumulations. Protalus ramparts are fairly frequent near cirque walls and are small in size, no more than $150 \mathrm{~m}$ long; they are generally on north-facing slopes where snow and nevé patches could remain longer. Only exceptionally do they appear active today. A similar observation was made by Barrère (1952), on the Vignemale massif where there are also some small glaciers.

Some of the highest talus slopes also connect with rock glaciers. These forms are relatively frequent in the Central Pyrenees, for the climate there is drier and more continental. This reaffirms the idea that rock glaciers are related to periglacial environments characterized by relative dryness and the prevalence of gelifraction (Jorda, 1984). Cazevane-Piarrot and Tihay (1984) and Angely (1967) have carried out studies on rock glaciers in the French Pyrenees; Serrat (1979) and Guiterrez and Peña (1981) have described them in the Spanish Eastern Pyrenees; their presence has also been mentioned by Soutade (1980) and Gomez-Ortiz (1984). All agree that they belong to a later stage than the Würm maximum. According to Serrat (1979) they belong to the late glacial period, although some of them appear to have been active until very recent times, or may be still active today. Rock glaciers are located within cirques, usually with shaded exposures and adjoin large northerly-oriented talus from which they appear to have received large blocks. Their dimensions are very variable, the largest examples being located in the French Pyrenees. Limestones and limestones with sandstone are sources for the best-developed rock glaciers. They also occur as well-developed forms beneath scarps of Paleozoic hard rocks that have a special tendency to produce great amounts of coarse sediment.

Talus and, secondly, rock glaciers are the largest forms that appear in relation to the frequent and periodic freezethaw activity in high mountain areas. Smaller forms include patterned ground and frozen soils which actually are phenomena that better define the periglacial environment; they require the presence of predominantly fine-grained materials mixed with medium-size clasts (less than $15 \mathrm{~cm}$ ). However, patterned ground sometimes develops on coarse materials as is the case of some stripes in the Monte Perdido massif.

Permafrost occurrence in the Central Pyrenees has been mentioned by Boyé (1952) and Barrère (1952) (Marboré Lake, Monte Perdido, North glacier), who deduce its presence from the summer mollisol. Monturiol (1959) also indicates the accumulation of frozen ground in midsummer, at about $2,400 \mathrm{~m}$ in the most shaded area of an avalanche channel on the Maladeta massif. Gomez-Ortiz and Serrat (1978) suggest the possibility of the existence of frozen soils on the Puigmal massif (Eastern Pyrenees), since the average temperature is below $0^{\circ} \mathrm{C}$ for six months at 2,200 $\mathrm{m}$ and for 8 months at 2,700 $\mathrm{m}$. The presence of various types of patterned ground indicates important ground-disturbance activity, such as ground freezing to a depth of $1 \mathrm{~m}$ seasonally or permanently, with mollisol formation in summer.

The polygons of the Monte Perdido massif were first mentioned by Gomez De Llarena (1936) and studied in detail by Boyé (1952) and Barrère (1952). They are floating polygons on gradients between 1 and 2 degrees, which in their centers comprise a sandy-silty material without gravel. They are located between 2,600 and 2,700 m. According to Barrère (1952) they begin as dessication cracks as a result of freezing, because together with stone polygons there are polygons in small areas which lack the necessary coarse material to facilitate sorting processes. When the slope is greater than 5 degrees polygons merge into stone stripes. In the vicinity of the Monte Perdido massif this kind of phenomenon is quite frequent, particularly on north-facing slopes.

Farther west patterned ground occurrences are exceptional, owing to the lower altitudes and to the greater winter snowfall. But eastward they become frequent again, especially at high elevation. Gomez-Ortiz and Serrat (1978) mention their presence at 2,250 $\mathrm{m}$. They are disorganized and re-sorted annually, since they occur in areas trampled by flocks of sheep. Tests made by GomezOrtiz (1982) on the Calmquerdos massif lead to the conclusion that polygons are active at present and also that their degree of activity relates directly to altitude. Gomez-Ortiz (1984) remarks that high plateaus and mountain passes are the typical environment for these geometric forms, where snow is frequently deflated and intense soil disturbance phenomena may appear. In the Central Pyrenees geometric forms are also related to wind intensity as on flat hill tops of Marbore Peak.

If snowfall is heavy and lasts until the beginning of summer, ground freezing is minimal and, in all cases, is limited to a shallow layer. Patterned ground cannot be formed, although stone pavements (dallages) are widespread. They usually occur on flats or slightly inclined slopes, close to small tors or micro-scarps which produce 
flat clasts. According to Soutade (1970b) stone pavements are not active, although we think they may be still active if we take into account freeze-thaw on other nearby scarps.
If stone size is very heterogeneous and blocks predominate, there is no chance of sorting. Blockfields are, therefore, unsorted.

\section{GONCLUSIONS}

The Pyrenean environment above timberline includes a wide variety of active and subactive processes which occur in response to ground characteristics, altitude, rock type, exposure, and microtopography. Altitudinal variation produces a distinction between two broad belts: in the lower belt precipitation phenomena and humid mountain mass movements occur with other processes associated with snow or frost action; the upper belt is characterized by the local existence of patterned ground and other processes in more or less direct response to frost action. The boundary between the two belts can be placed at about 2,400 m, although topography and exposure give rise to wide variations in some places. The Central and East-Central Pyrenees display the most clearly developed upper altitudinal belt because of their greater elevation and more continental precipitation regimes.

In all cases the role played by lithology is very important, as is topography which separates water and sediment production areas from those where water accumulates. However, in the lower belts the most important factor is the presence or absence of deep soils. Where soils are well developed, mass movements of different magnitude and speed are the predominant features; otherwise mass movements are very superficial and appear together with other surface wash forms.

Processes affecting deep soils show the importance of

\section{REFERENCES}

Alvera, B, and Puigdefabregas, J., 1985: Pulsación diaria de la carga suspendida y disuelta en la escorrentía de fusión nival. Cuadernos de Investigación Geográfica, 11: 5-20.

Allée, P., 1984: Environment géomorphologique et éboulis de gélifraction hérités dans le Haut Vallespir (Pryénées Orientales). Eboulis et environment géographique passé et actuel, pp. 31-34, Paris.

Angely, G., 1967: Anciens glaciers rocheux dans l'Est des Pyrénées centráles. Rev. Géogr. Pyr. S.O., (1) 5-28.

Barrère, P., 1952: Evolution mécanique et nivation sur les versants calcaircs de la haute montagne Pyrénéenne. Pirineos, 24: 201-211.

— 1956 : Notes relatives à l'évolution post-glaciaire des versants dans les Pyrénées centrales franco-espagnoles. Congre. Intern. Geogr., pp. 142-148, Amsterdam.

1966: La morphologie quaternaire dans le region de Biescas et de Sabiñanigo (Haut Aragon). Bull. Assoc. Franc. Etude Quat., 2: 83-93.

Boyć, M., 1952: Gélivation et crioturbation dans le massif du Mont-Perdu (Pyrénées Centrales). Pirineos, 23: 5-30.

Brosch, K. U., 1978: Formas actuales y límites inferiores periglaciares en la Peninsula Ibérica. Estudios Geográficos, 151: 131-162.

Cazenave-Piarrot, F. and Tihay, J. P., 1984: Eboulis, formations morainiques et glaciers rocheux dans lc massif de l'Ardiden (Pyrénées Gentrales). Eboulis et environnement géographique passé et actuel, pp. 121-136, Paris.

Creus, J. and Garcia-Ruiz, J. M., 1977: Observaciones sobre deforestation. Most slopes below 2,000-2,200 $\mathrm{m}$ were covered by forest which was cut down or burnt to provide an expansion of summer pastures for increased livestock grazing. This resulted in extensive lowering of the timberline and, hence, in lowering of the active solifluction limit (Hollermann, 1985). The present stability (at least in a relative sense) of forest-covered slopes contrasts with the remarkable geomorphic activity of the level immediately above. Many slopes are affected by sudden landslides which carry away all soil from those slopes with steep gradients, and cause accumulation on perched flats and at the bases of slope where low rates of solifluction are characteristic. Once these processes begin, terracettes appear in dry places, or dense nets or rills develop on rectilinear slopes. Forest cutting, in recent times, from the sixteenth to eighteenth cencuries, has caused a spectacular change in the dynamics of the lower periglacial belt.

Spring is the critical season for most active geomorphic activity. This is when melting coincides with precipitation maxima and with noctural freezing in those areas already without snow. Under such conditions, it is the melt period that favors the seasonal increasc in activity of all types of mass movements which may remain virtually inactive during the rest of the year. At the same time drainage channels transport maximum amounts of solid materials and solutes.

solifluxión en el Alto Valle del Río Gállego. Actas II Reunión Grupo Español Trabajo Cuaternario, pp. 57-64, Madrid.

Creus, J. and Puigdefabregas, J., 1976: Climatología histórica y dendrocronología de Pinus Uncinata Ramond. Cuadernos de Investigación Geográfica, 2 (2): 17-30.

Del Barrio, G. and Puigdefabregas, J., 1987: Mass wasting features above the timberline in the Central Pyrenees, and their topographic controls. Pirineos, 130: 3-25.

Garcia-Ruiz, J. M. and Puigdefabregas, J., 1982: Formas de erosión en el flysch eoceno surpirenaico. Cuadernos de Investigación Geográfica, 8: 85-128.

__ - 1984: Inestabilidad de laderas en el Pirineo Aragonés: Tipos de movimientos y su distribución geográfica. Jornadas sobre Inestabilidad de laderas en el Pirineo, pp. 141-152, Barcelona.

Garcia-Ruiz, J. M., Puigdefabregas, J. and Creus, J., 1985: Los recursos hídricos superficiales del Alto Aragón. Instituto de Estudios Altoaragoneses, $224 \mathrm{pp}$. Huesca.

—_ 1986: La acumulación de nieve en el Pirineo Central y su influencia hidrológica. Pirineos, 127: 25-72, Jaca.

Garcia Viñao, A., Alvera, B., Puigdefabregas, J., and Montserrat, P., 1986: Sistcmas de erosión en pastos del flysch eoccno surpirenaico. XVI Reunión de la S.E.E.P., pp. 233-248, Oviedo.

Gimenez, J. L., 1982: Glaciarismo y periglaciarismo del macizo Turbón (Huesca). Argensola, 93: 5-28.

Gomez De Llarena, J. , 1936: Algunos datos sobre el glaciar actual de Monte Perdido (Pirineos). Bol. Soc. Esp. Hist. Nat., $36(7)$ : 327-343.

Gomez-Ortiz, A., 1981: Nota sobre el conocimiento geomorfol- 
ógico de los modelos de acumulación y de erosión cuaternarios de la vaguada del Alto Segre. Notes de Geografía Física, 6: 49-69. , 1982: La experimentación periglacial en la alta montaña mediteránca. El caso de las microfliguraciones geométricas. Cuadernos de Investigación Geográfica, 8: 71-84.

, 1984: Los diferentes conjuntos de formas periglaciales de las áreas supraforestales pirenaicas. Notas de Geografía Física, 11: $17-30$

Gomez-Ortiz, A, and Serrat, D., 1978: Las formaciones geométricas periglaciares de los altos niveles del Pirineo Oriental. $V$ Coloquio de Geografía, pp. 75-81, Granada.

Gonzalez-Martin, J. A., 1986: Rasgos gencrales del periglaciarismo de la península Ibérica y áreas insulares. Dominio pirenaico y dominio subtropical de las islas Canarias. Munibe, 38: 133-154.

Gutierrez, M. and Peña, J. L., 1981: Los glaciares rocosos y el modelado acompañante en el área de la Bonaigua. Boletín Geológico y Minero, 92 (2): 101-110.

Hollermann, P., 1967: Zur Verbreitung rezenter Periglazialer Klcinformen in den Pyrenäc und Ostalpen. Gött Geograph. Abhandl, 40: 67-69.

_, 1985 . The periglacial belt of mid-latitude mountains from a geoecological point of view. Erdkunde, 39: 259-270.

Jorda, J., 1984: Eboulis et glaciers rocheux. Eboulis et environnement géographique passé et actuel, pp. 107-120, Paris.

Lavandier, P. and Mur, C., 1974: Ecologie d'un torrent pyrénéen de haute montagne. II. Caractéristiques chimiques. Annls. Limnolo., 10 (3): 275-309.

Leonard, R. L., Kaplan, L. A., Eider, J. F., Coats, R. N., and Goldman, C. R., 1979: Nutrient transport in surface runoff from a subalpine watershed, Lake Tahoe basin, California. Ecol. Monogr., 49 (3): 281-310.

I.lobet, S., 1975: Noticia de solifluxión periglaciar en Cataluña. Estudios Geográficos, 140-141: 661-672.

___ 1978-79: Esbós d'alguns fenómens periglacials á Andorra. Revista de Geografía, 12-13: 9-15.

Marti Bono, C, and Gonzalez, M. C., 1979: Nota sobre algunos depósitos coluviales del Alto Aragón. Actas III Reunión Grupo Español Trabajo Cuaternario, pp. 199-297, Madrid.

Monturiol, J, 1959: Sobre una forma periglacier descubierta en el Macizo de Vallibierna (Pirineo Central). Notas y Comunicaciones I. G.M.E., 55: 59-70.

Puigdefabregas, J. and Alvera, B., 1986a: Aspectos biogeoquímicos de los ambientes de montaña. Jornades sobre bases ecologiques per la gestió ambiental, pp. 79-84, Barcelona.

-, 1986b: Particulate and dissolved matter in snowmelt runoff from small watersheds. Z. Geomorph. N. F. Suppl. Bd. 58.

Puigdefabregas, J. and Garcia-Ruiz, J. M., 1983: Parametros fisicos del suelo y dinamica de vertientes en el Pirinco Central. VIII Coloquio de Geograficos Españoles, pp. 131-138, Barcelona.

$\ldots+, 1984$ : Dynamique des versants au niveau supraforestier: glissements massifs des sols anciens dans les Pyrénées Ccntrales. Documents d'Ecologie Pyrénéenne, 3-4: 449-454.

Serrat, D., 1977: Nota sobra unos derrubios estratificados en el Pirineo Oriental español. Actas II Reunión Grupo Español Trabajo Cuaternario, pp. 275-285, Madrid.

——, 1979: Rock glacier morainic deposits in the eastern Pyrenees. In Schluchter, C. (ed.), Moraines and Varves, A. A. Balkema, pp. 93-100, Rotterdam.

Sole-Sugrañes, L., 1973: Nota sobre el límite inferior de derrubios estratificados de vertiente en el sector de St. Llorenc de Morunys (Prepirineo Oriental). Acta Geológica Hispanica, 8 (5): $167-173$.

Soutade, G., 1970 a: Exhumation de sols polygonaux et dégradation de la pelouse d'altitude sur la Pla de Gorra Blanc. Bull. Ass. Géogr. Franc., 384.

____ 1970b: Formes de figuration de la bordure orientale du Pla Guillem (Pyrénées Orientales). 94 Gongrès National des Sociétés Savantes, pp. 17-24, Pau.

_- 1976: Détermination du caractère fonctionnel de certains éboulis lités des Pyrénées catalanes: les terregalls du Puigmal. Acta Geológica Hispanica, 2: 38-45.

-_ 1980: Modelé et dynamique actuelle des versants supraforestiers des Pyrénées orientales. Impr. Coop. Sud-Ouest., $452 \mathrm{pp}$.

Van Asch, T. W. J., 1980: Water erosion on slopes and landsliding in the mediterranian landscape. Utr. Geographische Studies, 20: 1-238.

Ventura, J., 1986: Aspectes del modelat glacial y periglacial a la Vall de Son. Revista Catalana de Geografía, 2: 57-69. 